\title{
УДК 616.1-003.96-02:616.895.8-036-071
}

\section{Н.С. Карвацька,}

\section{C.M. Русіна,}

\section{B.I. Курик,}

\section{Т.Г. Карвацька,}

\section{Р.А. Нікоряк}

Вищий державний навчальний заклад України “Буковинський державний медичний університет”, м. Чернівці

\section{ОСОБЛИВОСТІ АДАПТАЦІЙНИХ МОЖЛИВОСТЕЙ СЕРЦЕВО-СУДИННОЇ СИСТЕМИ У ХВОРИХ НА ШИЗОФРЕНІЮ}

Ключові слова: адаптаційні можливості серцево-судинної системи, иизофренія.
Резюме. Установлено збільщення гемодинамічних показників у хворих на шизофренію порівняно зі здоровими особами, щяо супроводжується статистично значимим збільшенням частоти напруження адаптаційних механізмів та дезадаптації сериевосудинної системи. Це засвідчує про значне зниження резервних можливостей організму та високий ризик розвитку соматичних ускладнень з боку сериево-судинної системи у хворих на шизофренію.

\section{Вступ}

Однією $з$ найбільш актуальних проблем сучасної психіатрії залишається шизофренія. Високий рівень хворобливості (до 10 випадків на 1000 населення), ранній початок захворювання (20 - 25 років) та тенденція хвороби до безперервного перебігу з інвалідизацією хворих визначають вагому значимість своєчасної діагностики та адекватного лікування з використанням засобів психологічної соціальної реабілітації, від яких значною мірою залежить прогноз захворювання [1]. За даними досліджень, хворі на шизофренію частіше і раніше вмирають, а середня тривалість життя на 29 \% менша, ніж у загальній популяції. Підвищена смертність при шизофренії зумовлена як насильницькими (нещасні випадки, вбивства, суїциди), так і природними причинами. Серед останніх актуальною постає серцево-судинна, неврологічна, дихальна, ендокринна, інфекційна, паразитарна, онкологічна патологія [2]. Значний вплив на смертність хворих на шизофренію виявляють такі розповсюджені у хворих на шизофренію фактори ризику, як малорухливий спосіб життя, підвищена вага, паління, ожиріння, підвищення рівня холестерину сироватки крові, артеріальна гіпертонія, цукровий діабет, які потребують вивчення $[3,4]$.

\section{Мета дослідження}

Вивчити особливості адаптаційних можливостей серцево-судинної системи хворих на шизофренію.

\section{Матеріал і методи}

3 дотриманням принципів біоетики проведено комплексне клініко-лабораторне та інструментальне обстеження 60 хворих віком від 20 до 50 років, які лікувалися в Чернівецькій обласній психіатричній лікарні щодо шизофренії (досліджувана група) та 60 здорових людей аналогічного віку (контрольна група).

Контрольну групу становили 60 практично здорових осіб віком від 20 до 50 років, з яких - 30 чоловіків (50 \%) та 30 жінок (50\%), середній вік становив $35,0+3,36$ років.

Досліджувану групу хворих на шизофренію становили 60 паціснтів Чернівецької психіатричної лікарні віком від 20 до 50 років, які знаходилися на стаціонарному лікуванні стосовно даного захворювання (чоловіки віком від 20 до 50 років - 30 осіб (50 \%), жінки віком від 20 до 50 років - 30 осіб (50\%). Середній вік хворих на шизофренію становив $37,21+4,25$ років.

Для оцінки адаптаційних ресурсів організму хворих на шизофренію визначали адаптаційний потенціал (АП) за формулою Р.М. Баєвського (1979): АП (в балах) $=0,011$ х ЧСС $+0,014 \times$ САТ + $0,008 \times$ ДАТ $+0,014 \times$ вік $+0,009$ х маса $-0,009 \times$ Ріст - 0,27, де АП - адаптаційний потенціал; ЧСС - частота серцевих скорочень; САТ - систолічний артеріальний тиск; ДАТ - діастолічний артеріальний тиск. Отриману величину перевели в оцінку АП системи кровообігу, користуючись шкалою: величина АП до 2,1 бала відповідає задовільній адаптації. При АП від 2,11 до 3,2 бала спостерігається напруження механізмів адаптації. При значенні АП від 3,21 до 4,3 бала - незадовільна адаптація. При показниках АП, що становить 4,31 і більше балів, відбувається зрив механізмів адаптації. 
Статистичну обробку даних здійснювали за методом варіаційної статистики з використанням критерію Стьюдента за допомогою комп'ютерних програм "Statgrafics" та "Exel 7,0". Статистично вірогідною вважалася різниця при величині показника $\mathrm{p}<0,05$.

\section{Обговорення результатів дослідження}

За даними вітчизняних дослідників, найбільш ранні порушення обміну білків, жирів, вуглеводів і водно-мінерального балансу при шизофренії маніфестують змінами нейровегетативної регуляції, які зумовлюють зміну характеру адаптивних реакцій, тобто можливість виникнення та перебіг психічних і соматичних захворювань $[5,6]$. Оскільки узагальненим індикатором реакцій пристосувального характеру всього організму виступає серцево-судинна система, то АП розглядається як комплексний показник регресійного взаємовідношення віку, показників функціонування системи кровообігу (частоти серцевих скорочень, систолічного та діастолічного артеріального тиску) та фізичного розвитку (маси тіла і зросту) [7].

У осіб контрольної групи середній зріст становив $168,37 \pm 3,35$ см. Середній зріст у осіб досліджуваної групи становив $169,25 \pm 2,38$ см, $(\mathrm{p}>0,05)$.

Середня маса здорових осіб - 64,59 $\pm 3,5$ кг, а у хворих на шизофренію дорівнювала 69,60 $\pm 3,30$ кг. Таким чином, абсолютні значення антропометричних показників (зріст і маса тіла) у групі осіб віком від 20 до 50 років знаходилися в межах вікової норми $(p>0,05)$. Достовірної різниці між антропометричними показниками в обстеженій групі хворих на шизофренію та здорових осіб не виявлено ( $\mathrm{p}>0,05)$.

Результати дослідження гемодинамічних показників (частоти серцевих скорочень та величини артеріального тиску - систолічного і діастолічного) у групі здорових осіб віком від 20 до 50 років виявили їх відповідність межам вікової норми. В осіб контрольної групи частота серцевих скорочень становила $69,59 \pm 2,5$ уд./ хв, систолічного артеріального тиску - 115,23 $\pm 1,32$ мм рт. ст., діастолічного - 75,23 $\pm 1,13$ мм рт. ст. В осіб досліджуваної групи хворих на шизофренію виявлено статистично значиме збільшення частоти серцевих скорочень до 83,30 $\pm 2,48$ уд./ хв, показників систолічного та діастолічного артеріального тиску до $126,30 \pm 1,34$ мм рт. ст. і $80,97 \pm 1,19$ мм рт. ст., відповідно $(\mathrm{p}<0,05)$.

Під час проведення досліджень оцінки адаптаційних можливостей у хворих на шизофренію встановлено, що високих чи достатніх функціональних можливостей організму (адаптаційний потенціал менше чи дорівнює 2,1 бала) було

Таблиця 1

Показники адаптаційного потенціалу у хворих на шизофренію в порівнянні зі здоровими особами

\begin{tabular}{|c|c|c|c|}
\hline \multirow[t]{2}{*}{ № 3/п } & \multirow[b]{2}{*}{ Стан АП } & Контрольна група & Досліджувана група \\
\hline & & $\mathrm{n}=60$ осіб & $n=60$ осіб \\
\hline 1. & Задовільна адаптація & 54 особи (90 \%) & 6 осіб (10\%) \\
\hline 2. & $\begin{array}{l}\text { Напруження механізмів } \\
\text { адаптації }\end{array}$ & 6 осіб $(10 \%)$ & 45 осіб $(75 \%)$ \\
\hline 3. & $\begin{array}{l}\text { Незадовільна адаптація, } \\
\text { дезадаптація }\end{array}$ & 0 & 9 осіб (15\%) \\
\hline 4. & $\begin{array}{l}\text { Зрив механізмів } \\
\text { адаптації }\end{array}$ & 0 & 0 \\
\hline
\end{tabular}

Примітка: * - значення показника в порівнянні $з$ контролем статистично вірогідно $(\mathrm{p}<0,05)$. лише у 6 осіб (10\%) (Таблиця 1).

У 54 (90\%) хворих на шизофренію спостерігається напруження адаптаційних можливостей $\mathrm{i}$ незадовільна адаптація, що призводить до дезадаптації. Водночас в осіб контрольної групи задовільну адаптацію виявили у 54 (90 \%) осіб.

Стан напруження адаптаційних механізмів (показник $2,1-3,2)$ у хворих на шизофренію становив у 75\% (45 осіб), що в 7,6 раз більше, ніж у контрольній групі. Серед осіб контрольної групи з такими можливостями виявлено 6 (10\%) осіб.

Порушені адаптаційні механізми у вигляді дезадаптації (коефіцієнт більше 3,2 ) серед хворих досліджуваної групи встановлені в 9 осіб (15\%). Серед контрольної групи осіб з таким порушенням адаптаційних механізмів не виявлено. Зриву адаптації в контрольній і досліджуваній групі не виявлено (показник більше або дорівнює 4,31 бала).

Проведені дослідження оцінки адаптаційних можливостей хворих на шизофренію показали, що високих чи достатніх функціональних можливостей організму не виявлено. Водночас в осіб контрольної групи таких зафіксовано 48 (80\%).

Таким чином, у хворих на шизофренію достовірно частіше спостерігається стан напруження 
адаптаційних механізмів та дезадаптації. Це вказує на значне зниження резервних можливостей організму та збільшення ризику розвитку соматичних ускладнень у хворих на шизофренію.

Провівши аналіз середніх значень показників адаптаційного потенціалу серцево-судинної системи хворих на шизофренію, встановили, що високих чи достатніх функціональних можливостей організму (адаптаційний потенціал менше чи дорівнює 2,1 бала) не було. Серед осіб контрольної групи показник адаптаційного потенціалу в середньому склав 2,29 + 0,14 балів, що відповідає стану напруження АП (показник 2,1-3,2). У пацієнтів досліджуваної групи показник стану адаптаційних механізмів статистично вірогідно збільшився до $2,79+0,15$ бала і відповідав стану напруження

Таблиця 2

Середні значення показників адаптаційного потенціалу серцево-судинної системи хворих на шизофренію у порівнянні зі здоровими (M $\pm \mathbf{m})$

\begin{tabular}{|c|l|c|c|}
\hline \multirow{2}{*}{ № 3/п } & \multicolumn{1}{|c|}{ Стан АП } & Контрольнагрупа & Досліджувана група \\
\cline { 3 - 4 } & \multicolumn{1}{|c|}{$\mathbf{n}=\mathbf{6 0}$} & $\mathbf{n}=\mathbf{6 0}$ \\
\hline 1. & Задовільна адаптація & - & - \\
\hline 2. & $\begin{array}{l}\text { Напруження механізмів } \\
\text { адаптації }\end{array}$ & $2,29 \pm 0,14$ & $2,79 \pm 0,15 *$ \\
\hline
\end{tabular}

Примітка: * - вірогідність ознаки за Стьюдентом, значення показника у порівнянні 3 контролем статистично вірогідно $(\mathrm{p}<0,05)$. адаптаційних резервів $(\mathrm{p}<0,05)$ (Таблиця 2).

\section{Висновки}

Застосовані клініко-функціональні критерії й диференціально-діагностичні таблиці АП дозволили визначити рівні адаптаційних можливостей серцево-судинної системи (задовільний, напруження, незадовільний) та виявити їх зниження у 90 \% хворих на шизофренію. У хворих на шизофренію виявлено збільшення гемодинамічних показників (частоти серцевих скорочень, показників систолічного та діастолічного артеріального тиску порівняно зі здоровими особами, що супроводжується статистично значимим зростанням частоти напруження адаптаційних механізмів та дезадаптації серцево-судинної системи, що вказує на значне зниження резервних можливостей організму та високий ризик розвитку соматичних ускладнень 3 боку серцево-судинної системи.

Перспективи подальших досліджень полягають у дослідженні вікових та статевих особливостей адаптаційних можливостей організму хворих на шизофренію з метою виявлення груп ризику щодо можливого порушення процесів адаптації, розробки індивідуальних і колективних програм підвищення резервів здоров'я, що буде сприяти поліпшенню ефективності лікування і якості життя хворих.

\section{Перспективи подальших досліджень}

Подальші дослідження полягають у вивченні вікових та статевих особливостей адаптаційних можливостей організму хворих на шизофренію 3 метою виявлення груп ризику щодо можливого порушення процесів адаптації, розробки індиві-

дуальних і колективних програм підвищення резервів здоров'я, що буде сприяти поліпшенню ефективності лікування і якості життя хворих.

Література. 1.Баевский Р.М. Оценка адаптационных возможностей организма и риск развития заболеваний / Р.М. Баевский, А.П. Берсенева. - М.: Медицина, 1997. - 236 c. 2.Бурлаков А.В. Шизофрения и расстройства шизофренического спектра, коморбидные сердечно-сосудистой патологии (клиника, психосоматические соотношения, терапия): дис... канд. мед. наук: 14.00.18 / А.В. Бурлаков. - М., 2006. - 218 с. 3.Волков В.П. Кардиологические причины смерти больных шизофренией / В. П. Волков// Соц. и клин. психиатрия. - 2012. - Т.22, № 4. - С. 41 - 44. 4.Малацківська О.В. Зв'язок між традиційними факторами ризику розвитку серцево-судинних захворювань та тривожно-депресивними станами у жінок / О.В.Малацківська, I.М. Горбась // Укр. кардіол. ж. - 2005. - № 6. - С. 97 - 99. 5.Марута Н.А. Проблемы коморбидности в современной психиатрии. Теоретический, клинический, терапевтический и организационный аспекты / Н. А. Марута // Здоров'я України. - 2013 р. № 4. С. 38 - 39. 6.Подвигин С.Н. Особенности проявлений негативных расстройств и нейрокогнитивного дефицита у больных параноидной шизофренией с коморбидной артериальной гипертензией / С.Н. Подвигин // Вестн. нов. мед. технологий. - 2010. - Т. 17, № 2. - С. 138 - 140. 7.Friedman J.I. The effects of hypertension and body mass index on cognition in schizophrenia / J.I. Friedman // Am. J. Psychiatry . - 2010. - № 167 (10). - Р. 123 - 139. 8.Шизофрения и повышенный риск сердечно-сосудистых заболеваний / C.H. Hennekens, D.E. Casey, A.R. Hennekens, D. Hollar // Психические расстройства в общей медицине. - 2008. - № 2. - С. 59 - 62. 9.Leucht S. Physical Illness and Schizophrenia: A Review of the Evidence / S. Leucht. - Cambridge University Press., 2007. - 224 p. 10. Lev Ran S. Impact of hypertension and body mass index on quality of life in schizophrenia / S. Lev Ran, Y. Le Strat, B. Le Foll // Am. J. Psychiatry. - 2011. - № 168(5). - P. 552 - 553.

\section{ОСОБЕННОСТИ АДАПТАЦИОННЫХ ВОЗМОЖНОСТЕЙ СЕРДЕЧНО-СОСУДИСТОЙ СИСТЕМЫ У БОЛЬНЫХ ШИЗОФРЕНИЕЙ}

Н.С. Карвацкая, С.Н. Русина, В.И. Курык, Т.Г. Карвацкая, Р.А. Никоряк

Резюме. Установлено увеличение гемодинамических показателей у больных шизофренией по сравнению со здоровыми лицами, что сопровождается статистически значимым увеличением частоты напряжения адаптационных механизмов 
и дезадаптации сердечно-сосудистой системы. Это свидетельствует о значительном снижении резервных возможностей организма и высоком риске развития соматических осложнений со стороны сердечно-сосудистой системы у больных шизофренией.

Ключевые слова: адаптационные возможности сердечно-сосудистой системы, шизофрения.

FEATURES OF ADAPTATION POSSIBILITIES OF CARDIOVASCULAR SYSTEM IN PATIENTS WITH SCHIZOPHRENIA

N.S. Karvatska, S.N. Rusyna, V.I. Kuryk, T.G. Karvatska, R.A. Nikoriak

Abstract. It has been established an increase in of hemo- dynamic parameters in patients with schizophrenia compared with healthy people, accompanied by statistically significant a increase of frequency of stress adaptation mechanisms disadaptation of cardiovascular system. This demonstrates the significant reduction of reserve possibilities of the organism and high risk of physical complications of the cardiovascular system.

Key words: adaptive possibilities of the cardiovascular system, schizophrenia.

Higher State Educational Establishment of Ukraine "Bukovinian State Medical University", Chernivtsi Clin. and experim. pathol.- 2017.- Vol.16, №1 (59).-P.79-82. Надійшла до редакиії 5.01.2017 Речензент - проф. О.С. Полянська (c) Н.С. Карвацька, С.М. Русіна, В.І. Курик, Т.Г. Карваџька, P.A. Нікоряк, 2017 